\title{
Harnessing the Barriers That Impact on Students' English Language Learning (ELL)
}

\author{
Hussain Ahmed Liton \\ Lecturer, English Language Centre, Jazan University, Jazan, Saudi Arabia, \\ husal@jazanu.edu.sa
}

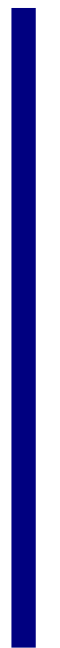

This study strives to single out the barriers and obstacles in terms of academic, course curriculum system and socio-cultural issues that impact on students' learning English language adversely in the prep year level at Jazan University, Saudi Arabia. This paper especially focuses on the factors affecting EFL (English as a Foreign Language) students' teaching/learning engagement and progression at Jazan Community College (JCC) based on the semi interview of teachers, administrators and classroom observations. The author administered the interview process based on a questionnaire and at the same time, the interviewees' reflections were noted down. The recorded data were analyzed qualitatively and quantitatively. The results of the research are expectedly surprising and contributing to EFL educational improvements and adjustments for all stakeholders in terms of instructional effectiveness. The data analysis in particular showed that most of the interviewing voices reflect students' negative stance towards learning English due to cross-cultural factors, lack of motivation and EFL teaching method and curriculum strategic defects in pre-university stage. In addition, this paper hypothesizes some effective and viable suggestions based on research investigation.

Key Words: communicative competence, linguistic barriers, socio-cultural awareness, English for learning purposes, English learners (ELs)

\section{INTRODUCTION}

In any educational context and scenario, teaching-learning effectiveness is filtered through students' learning motivation and success. At this turn of $21^{\text {st }}$ century, multimodal instructional facilities and paradigms accelerate the success of learning effectiveness. Despite this, learning barriers and obstacles are common phenomena even in the most successful seats of learning across the globe. Barriers to learning for students in general may be personal, emotional, economic, attitudinal, situational or even organizational. The initiatives to recognize the diversity within the academic affairs, student population and the dynamics of learning paradigms especially the aspects of individual differences, institutional shortcomings and surrounding sociocultural issues are expected to help the teachers/institutions to diagnose the barriers to 
learning in general, and minimize them more or less. In 'so' doing, curriculum materials should be diverse, selective and appropriate including high tech material, e-learning resources, rather than focusing on traditional textbook(s). Barriers to participation in higher education can be many reasons and factors like academic, cultural, institutional, situational, financial or related to the complexity of instructional materials so far as the learner-groups are concerned. Behind such promising backdrop, this study attempts to explore the issue harnessing the barriers that impact on students' learning English at Jazan Community College (JCC) of Jazan University.

\section{Focus of the Study}

The study especially focuses on teaching/learning English and students' learning barriers at Jazan Community College (JCC).Teaching of English at JCC serves two purposes: first, it strengthens the foundation of English and later emphasizes on Specific English, i.e., ESP (English for Specific Purposes) which will support in studying the years of the students' specialties. English in the Kingdom is taught at school levels also, but it does not enjoy as important place in the curriculum as in most developing countries. Despite appropriate designing, curriculum, textbooks, teaching method and effective administration, the teaching-learning process sometimes seems to be futile when the actual skill development is not up to the mark. However, there could have been greater change, if a systematic analysis had been made in the past by exploring the factors responsible for students' learning obstacles and their low level of performance.

Both the teachers and learners face challenges for many reasons. The teachers face challenges due to the following: students' poor background knowledge in English, bilingualism in teaching (in Arabic context), psychology of the learners, language policy, status of English, methods and strategies, assessment system and the like. The learners face challenges mainly due to the following: the difference between the past and present style of teaching, technique of exams, and workload, more focus on English language activity and focused teaching, stricter evaluation system, hard work, lack of proper motivation and attitude to English. Management of such pedagogic challenges is inevitably a difficult task. Therefore, the role of management becomes more crucial at the EFL classroom situations. Behind such standpoint, this paper attempts to single out the barriers that impact on students' learning English with a view to lowering language barriers in dealing with their specialities subjects/disciplines of studies.

\section{The case of Jazan Community College (JCC)}

Jazan Community College (JCC) is dedicated to community services. It serves the society, and for this very purpose, it was established in 1419 H (1999 AD) in Jazan to serve the people of this region. Since 2006 it has become an affiliated institute of Jazan University, and later has been accredited by the Commission of the Council on Occupational Education, USA for recognition. It offers the Associate Degree in different disciplines, namely the Department of Administrative Sciences, and the Department of Computer and Information. 
These departments offer the Associate Degree in the following specialties:

\author{
1. Department of Administrative Sciences \\ - Accounting \\ - Business Administration \\ - Marketing \\ - Hotel and Tourism Management \\ - Office Management
}

\title{
2. Department of Computer and Information \\ - Computer Programming and Operation \\ - System Analysis and Design
}

Here, students who get admission into different disciplines possess low level of grade points in pre-university level and lack of motivation in learning. The course study span covers a period of three years divided into six levels. There are two levels in each year; the first consists of preparatory year and the rest is for specialization courses. It offers high-quality, student-friendly, and easily accessible educational resources with a view to preparing a qualified generation of outstanding responsible cadres and professionals. To this end, this college lays emphasis on English language to meet the challenges of the global market and professional needs. In the preparatory year, students are taught intensive courses in English such as ENG019: English Language I, and ENG020: English Language II. ESP is taught in the Level-II to gratify the learners' practical and specific needs.

\section{Review of Literature \\ Teaching/learning Paradigm}

In any educational and instructional process, teaching-learning takes place through numerous efforts and ramifications. In this process, learners and teachers experience hurdles and barriers that affect teaching/learning adversely. Such barriers are common phenomena in any context and situation in the arena of education. But, situations may vary from one place to another. Barriers among students to learning may include those factors that sometimes can easily be reduced or relegated. But, in certain cases, the barriers like natural disaster, physical disability or limitations become almost impossible to solve or minimize. This section of the present paper strives to explore the literature related to the shores of barriers that impact on students' learning English language in the tertiary level in various situations across the cultures and nations.

Dr. Intakhab Alam Khan (2011, pp. 68-80) in his research findings divulges some obstacles and challenges in teaching/learning English language in Saudi Arabia, especially in Community College, Jeddah of King Abdulaziz University. He spells out some important challenges experienced by the teachers and these are practically affecting students' learning advancement as barriers, such as: differences in the alphabet and the script between English and Arabic, word structure, punctuation, verbs and sentences, Noun cases in Arabic, Preposition, Conjunction, position of adjectives, use of 
subject, tense: indefinite and continuous, negligence to pronunciation, use of article, use of has/have, Subject-verb agreement and placement. In addition, he mentions some socio-cultural factors that adversely manipulate students' EFL learning, such as: relaxing personality, no pressure from the society or family, education is not taken as a source of income and development, less opportunity to practice English outside classroom, and lack of home environment for homework or self study.

\section{Cultural Issues Affecting Students' Learning}

Culture governs the life style and psychological sensitivity of people. Brisk pointed out that culture has an impact on Arabic-speaking ESL students' interactions in the classroom. She gave an example of Sudanese Muslim girls who disengaged from interacting with boys in their groups. This disengagement occurred as a result of their own culture that needs to be understood by teachers in order to help students fully engage in classroom activities (Brisk, 2010, pp. 152-173). In addition, Santos \& Suleiman believed that teachers can support Arabic-speaking ESL students by adjusting their curriculum to include the students' culture related materials and lifestyle. In textual gallery, for example, teachers can include the contributions of Arab scholars during medieval Islamic civilization in different fields, such as medicine (Ibn al-Nafis, IbnSina, Al-Razi, and Ibn al-Haytham), geography (Al-Idrisi, Ibn-Batuta, and IbnKhaldun), mathematics (Al-Khwārizmī), chemistry (Ibn Hayyān), and other disciplines (Santos \& Suleiman, 1993, pp. 175-180).

Cultural barriers affect students' learning process and so, cultural awareness and culturally relevant teaching materials can enhance EFL learning and intercultural communication. In this regard, Omran Akasha in his research in Saudi context points out “...six challenges: time, cultural awareness, cultural understanding, language support, teacher education/guidance, and parents' communication.... In addition, teachers and students can pay attention to cultural awareness because gaining awareness can help teachers provide their students authentic tasks and hence support them ..., and it can also help students participate more easily" (Akasha, 2013, pp. 12-31).

\section{Linguistic Barriers}

A number of research portfolios reflect on EFL learners' difficulties in learning English at various levels with different linguistic skills. According to Hayat Al-Khatib, Hamdan and Amayreh (2007) underlined phonological and articulatory problems for Jordanian learners. Kambal (1980) reported syntactic problems for Sudanese and Egyptian learners (as cited in Khatib, 2013, pp. 28-43).

Arab EFL learners experience some difficulties in English language pronunciation due to L1 influence and some of the sound systems are absent in Arabic phonemic sound. Hussam Rajab demonstrates some important and notable learning obstacles of Saudi EFL learners. His research outcome unveils "The greatest difficulty the students faced was the alternations of letters $-\mathrm{P} /$ and $-\mathrm{B} /$. Nearly $50 \%$ of the students were not able to distinguish between these two letters in writing, pronouncing (words having $-\mathrm{P} /$ or $\mathrm{B} /$ in them) and even in transcribing them. Again that may well be traced back to the fact that Arabic language lacks the sound $/ \mathrm{p} /$ - (Ibrahim, 1978) and therefore (that is) 
approximated to the nearest Arabic letter (ب)/B/ 'which is allophonic to /P/ (as cited in Rajab, 2013, pp. 653-659).

Arabic being the L1, Saudi EFL learners encounter difficulty in English pronunciation in some specific areas of phonetic systems. Fahad Alfallaj in his research findings in Saudi context showed that sounds whether vowels or consonants which do not exist in Arabic are difficult for Saudi learners (Alfallaj, 2013, pp. 134-143). Interestingly, during the classroom observation, it is found that Saudi English learners (ELs) commit mistakes in spelling and some specific English sound systems like P/ \& B/. They articulate /B/ in place of $/ \mathrm{P} /$. That's why; they spell Blease in place of Please. In addition, some of the learners fail to distinguish the letters between $b$ and $d$ in writing system. This issue affects Arab EFL learners' learning process and instructional effectiveness.

Choudhary Zahid Javid \& Muhammad Umer identified some problems and weaknesses of Saudi EFL learners especially in regard to language skill. Their research investigation reported that Saudi EFL learners have serious problems in their academic writing due to their weaknesses in using appropriate lexical items, organisation of ideas and grammar. The other weaker areas include wrong use of prepositions, spellings, irregular verbs, articles, punctuations, suffixes and prefixes. Behind such learning hurdles and obstacles, they suggested implementing a stricter admission policy, increasing language courses, developing tailor-made activities, providing increased practice in academic writing, exploiting modern teaching techniques and equipping the classrooms with modern teaching aids to improve Saudi EFL learners' academic writing (Javid \& Umer, 2014, pp. 164-180).

In addition, Saudi students suffer from the pitfalls of language structural defects in spoken and written forms more or less in all most all the levels of the tertiary setting. In a recent survey conducted by Ibrahim Fathi Huwari \& Fadi Maher Al-Khasawneh at Taibah University "Yanbu Branch" in Saudi Arabia to determine the students' weaknesses in writing skill, the findings of the study revealed that grammatical weakness, knowledge and understanding, less practice oriented teaching and poor educational background were the main concerns (Huwari \& Khasawneh, 2013, pp. 1-9).

\section{Pedagogical and Social Issues}

Despite teaching learning problems and obstacles, teachers as the prime motivator and implementer of curriculum can do miracle by minimizing the vexing gaps of students' needs and socio-cultural barriers. In this context, researchers and curriculum designers come across some feasible suggestions and point out that regarding the pedagogic issues "... the teacher has to be well equipped, and make a diagnostic study in order to analyze linguistically the nature and type of difficulties that the Saudi learners face during the course of study" (Khan, 2011, pp. 68-80).

In any EFL context, learners have less opportunity to expose and practise the target language in social and public context. Problems confronting Arab students during the course of learning English language exist in a large number. First of all, Saudi students are neither exposed to listening / speaking activities in their daily life interaction in public spheres, nor in school / college / university, or at home. Such conditions dampen 
the spirit and stunt the growth of the pupils' speaking skill. By virtue of their personal efforts, some students achieve a considerably good level of fluency in spoken English. However they miserably lag behind in other active skill that is writing. Findings of the study conducted by Intakhab Alam Khan, Abdul Haq (1982) conclude that most Arab students usually fumble in their writing skill. In his study, he further reveals that most English instructors and University officials complain about the continuous deterioration of the mastery of English language among the students (as cited in Khan, 2011, pp. 1248-1257). Typically, a common scenario for almost all Arab students enrolled in EFL classes is that they have a poor oral communication skill as they usually commit gross lexical and pronunciation errors. It happens due to their L1 influence and lack of the use of target language in real life communication as well as pronunciation difficulties. For instance in this regard, Zughoul \& Taminian cites that "Jordanian EFL students commit serious lexical errors while communicating in English" (Zughoul \& Taminian, 1984, p. 4).

\section{Saudi Language Policy}

The Ministry of Higher Education is highly concerned with the development of education system in the kingdom and introduced English as a medium of instruction in all higher educational institutions across the Kingdom. Arabic being the mother tongue is used as the only medium of instruction in all schools up to the secondary level. With the introduction of English as the language of instruction in undergraduate level, this sudden shift in language produces a barrier to the students and creates communication as a problematic issue in classroom teaching/learning. All the universities have their separate English Language Centre (ELC) as well as Preparatory Year Program (PYP) where they intensively train and prepare students for English language competence. This language difficulty is faced especially by the Prep Year students tremendously. In this regard, Ebad Ryhan diagnoses the fact that Arabization is also a major contributing factor in making the situation difficult. Students and instructors encounter high level of challenges and obstacles during the course of classroom instruction at the beginning of tertiary level (Ryhan, 2014, pp. 140-148).

Students, having two contrasting styles between spoken and written forms in English and Arabic texts, encounter many difficulties and obstacles in their academic writing. Regarding this point, Hind Al Fadda implies that “...English as a second language (ESL) students face many difficulties and stresses in their academic writing, such as difficulty in distinguishing between spoken and written English" (Fadda, 2012, pp. 123130). Actually, "Factors attributing to these differences include: a) differences in alphabets and b) differences in writing styles as well as Arabic tends to have more metaphoric phrases and lengthier sentences than English does" (Huwari \& Khasawneh, 2013, pp. 1-9).

Seemingly, it appears that the diverse literature review related to the barriers which have impact on students' learning English underpins the urgency and necessity of introducing collaborative modern pedagogic portfolio as well as heightens the effective learning process and the significance of the present study at this turn of $21^{\text {st }}$ century digital literacy skills. 


\section{METHOD}

\section{Research Context and Participants}

The study was conducted at Jazan Community College (JCC) of Jazan University, Saudi Arabia.

The participants of this study were highly experienced EFL teachers and administrators. A total of 8 teachers of English out of 11 and 4 administrators took part in this study (See Appendix).They were chosen on random basis. Some of the interviewee participants delivered similar information and so, their names are not revealed in the appendix. The respondents voiced their ennui of expressions regarding ELL academic scenario. It is expected that this survey research will reflect available insights into the barriers to learning English as well as the pathways of devising and catering to the learners' real needs oriented EFL course-curriculum.The demographic information concerning the people of diverse age group took part in this study.

\section{Data Collection Procedure}

Survey methodology was facilitated through conducting a semi-interview with the use of a questionnaire. The interview session was conducted at different convenient scheduled times of the participants during the office hour between November and December of 2014. In interview process, the interviewees' voice message was noted down based on the question-answer process. The interview of this survey was conducted to determine the teachers and administrators' self-reported reflections, comments and suggestions for capturing the ground reality of ELL obstacles as "personal reflections are integral to the emerging analysis of a cultural group, because they provide the researcher with new vantage points and with opportunities to make the strange familiar and the familiar strange" (Marshall \& Rossman, 2006, p. 100). In addition, several times classroom observation also conducted during the academic session 2014-2015 ( ${ }^{\text {st }}$ semester $)$. The interview questions were:

1. What are the obstacles and barriers that you experience affecting students' learning at JCC?

2. What's your suggestion to improve students' learning English?

\section{Data Analysis}

This paper administered quantitative and qualitative data analysis technique. From the collected data of interview and classroom observation, the participants' message was sorted out into a structured answer and effective issues related to students' learning barriers and possible trajectories were singled out for academic progression and effectiveness. Typically, throughout the data analysis processes, there was an attempt of the author "... to identify and describe patterns and themes from the perspective of the participant(s), then attempt to understand and explain these patterns and themes" (Creswell, 2003, p. 203). Results were reported both quantitatively and qualitatively. 


\section{FINDINGS}

\section{Interview Message}

In an interview with Mr. Ahmad Ali Majrashi (See Profile-1), the interesting and arresting information was captured. He spells out the pitfalls of existing traditional teaching approach. He thinks that if teachers apply learning technologies, i.e., Website, YouTube, Social media and computer/Tab/M-learning technique in teaching, students will be encouraged and motivated in learning process. By contrast, he happens to cite that in traditional instructional system, black-board, chalk-pencil, white-board marker, lecturing and merely reading \& writing technique bring monotony and it will be boring to the students and all these do not expose learners to a variety of learning situations and portfolios as maxim goes "variety is the spice of life" (KNOWLES, 2006).

In addition, he mentions some barriers and problems related to teaching/learning at Jazan Community College. These are cited here:

i) Timing in Class: Students are not on time in attending the lectures and not preparing themselves for pre-lecture preparatory lesson at home.

ii) Cultural Background: Sometimes cultural background helps students' learning in advance but sometimes also acts as a barrier to learning process. He brings a contrasting picture between rural and town/city background students:

\begin{tabular}{lllr}
\hline & students & those enrolled \\
\hline City background: & $\begin{array}{l}\text { Advanced in all } \\
\text { the respects }\end{array}$ & comparatively & \\
\hline Village background: & $\begin{array}{l}\text { Poor, Not disciplined, } \\
\text { Health problem, }\end{array}$ & $\begin{array}{l}\text { Not social, parents } \\
\text { indifference/ irresponsibility }\end{array}$ \\
\hline
\end{tabular}

He adds that some students are difficult to manage in the classroom because of their poor family and cultural background, especially village oriented pupils. In the village, people are commonly less privileged, poor, and more or less, lacking chances of discipline and socialization. All these affect students' over all learning into a fiasco.

iii) Academic and Curriculum Affairs: Poor facilities to teaching materials like smartroom, technology, and out dated instruments are unfit for the environment and students' facility. Full-fledged language lab is not available.

iv) Practical and Personal Barriers: Mr. Majrashi as an administrator experiences more practical and personal barriers to students' learning. Some students are from a long distance having no personal transportation facility. They come to university by Taxi and sometimes by fellow students' car. It costs a lot of money and affects their arrival at the classes in a timely fashion. He adds that a suitably devised core curriculum is required to capture students' practical academic needs and $21^{\text {st }}$ century literacy skills.

Mr. Turki (See Profile-1) in his interview expressed his concern over the unequal English language curriculum system between university and pre-university level. University course is in English medium but in pre-university learning stage, there are no 
such courses in English. Even at pre-university level, students did not study English language, or some of them studied English in a minimal unit which is not effective for advance level studies. Consequently, students face serious problem during first year studies in tackling their courses in English. Essentially, it is a dreadful issue for the weaker students of Community College in the kingdom.

Dr. Atef Mohammad Naser (See Profile-1) as an experienced professor reflected very important and remarkable issues concerning teaching/learning matters in Jazan University. He re-iterated the same issue, i.e., students having no background knowledge in English due to pre-university unsuitable curriculum system which is also mentioned by other interviewees. He spoke some other essential points that affecting students' learning. These are elucidated below:

i) Attitude to English: Some students have a belief that English is the language of nonMuslim and it will contaminate their religious belief. They continue to ask: Do English people learn Arabic? No, they don't. So, why do I learn English if they don't? These questions reflect their demotivation to learning English as a language of communication.

ii) Certificate of Community College Degree: Diploma certificate of Community College is not honoured so much by the employers in job market. As a result, it develops a kind of demotivation among Community College students. Practically, they need more valuable mode of academic certificate.

iii) Excuses and Existing Syllabus Inadequacy: Students those who come from distant places leave their classes on excused basis. It causes disjunction between the lessons among the students and it affects their performance in examinations. In addition, English course curriculum is a bit difficult and does not complement students' real academic needs. JCC syllabus will be different from other colleges. He thinks Elementary English courses will be fit for JCC students and Pre-Intermediate English courses will be suitable for Arts and advanced level students.

iv) Suggestion: He voiced for some remedial suggestions for remission of deterioration of students' academic learning at JCC. Communicative teaching method will be followed. Course curriculum will contain communicative practical materials, such asbasic grammatical lesson, Writing- emails, cover letter, job application, memo's; speaking- about myself, conducting meeting, and so on.

Mr. Jamal M. Ahmed (See profile-1) found some remarkable issues related to students' barrier in learning English at JCC. His voice determined that regular absences, carelessness, lack of family follow-up make students dis-collegiate in studies and exams. From his voice, some useful advice is followed. He spells out that technology-enhanced teaching can be a boosting point in motivating students' zeal for learning. Moreover, financial stipend for JCC students can motivate them in studies. He censured existing Pre-Intermediate English text book for JCC as an unpractical and recommended the lower level of book like Elementary Headway Series by Liz \& John Soars published by Oxford University Press.

Mr. Md. Khurshed Alam (See Profile-1) pointed out that teachers' motivation is needed in terms of financial issues and security assurance. 
Interestingly, it is important to note that some interviewee teachers and administrators at JCC expressed almost the same issues and factors that affecting students' learning viciously. That's why; their data and names are not mentioned here.

\section{DISCUSSION}

Current study throughout the data analysis process attempted to single out convergent and divergent issues concerning teachers and academic administrators' perceptions and evaluation about EFL students' learning barriers. This study comes across some common practical barriers to learning namely, students' transportation problem; late arrival to the lectures, physical disability; parents' lack of caring responsibilities; cost \& finance; weak background language skill and lack of access to information related to learning materials.

Research analysis also highlights some factors related to socio-cultural background and course curriculum systems which are affecting JCC students' EFL learning. In terms of socio-culture, course materials/ curriculum system, and learners' background knowledge, most of the interviewee voices reflected that students have negative attitude to learning English and lack of motivation because of deficiency in English language skill and unsuitable pre-university English teaching method and curriculum strategic defect. Surprisingly, data analytical findings bring to focus that technology-mediated teachinglearning situation captivates and motivates students' immersion in learning more than traditional pedagogy. In addition, the data analysis and research review reflected the following essential points of hypotheses:

\section{Issues of Barriers and Challenges:}

Some realistic problems aggravate the challenges of EFL teaching/learning and baffle the effectiveness of emerging a new mode of learning at this turn of digital era. The issues of challenges are:

\section{Curriculum Defect:}

Core curriculum contents do not capture students' practical academic needs. Course materials at pre-university stage (Secondary + Intermediate) are not tailored properly to prepare students for tertiary level studies so far as English medium of instruction is concerned. Actually, there is a huge gap and lack of assimilation between pre-university and university curriculum system. In addition, the course contents are not related to students' socio-cultural context and background and stories are derived from foreign events and contexts. It affects students' psychological and attitudinal levels. If course curriculum content is related to students" socio-cultural background, it will be "...effective in increasing students' learning motivation because it relates to their fields of study and caters to their needs" (as cited inTsao, 2011). In this vein, Lee (1995) states that "a careful and wise selection of materials focused on learners is a must if we want a positive response from them".

\section{Teaching Methodology:}

In pre-university stage, improper teaching/learning techniques affect students' learning. For example, continuous bilingual assistance in classroom and reading (Reading practice) at word/sentence level instead of relying on contextual clues to deal with unfamiliar lexical items do not develop students' calibre in English. Consequently, they fail to adjust with English medium teaching/learning in tertiary setting. In addition, selection of course material 
does not match with students' real needs and so, they cannot perform well in succeeding levels at university.

Some participating teachers suggested teaching particularly by citing examples in the classroom and assigning some homework from the exercise of the text book. This will engage and develop students' learning and perception of the lesson taught.

\section{Socio-cultural Effect:}

EFL learners face lack of options for practice English outside the classroom. In the public domain, people are not using English for daily conversation and communication. This lack of option for practice is considered as one of many factors barring students' learning English. Actually, students need to discharge and apply what they have learnt in classroom. Even socio-cultural environment is not facilitating students' to learn and practise English. For example, signboard of shops, supermarkets, roads and streets are mostly in Arabic. If there is few in bilingual, they are full of mistakes in spelling.

\section{Pronunciation Barriers:}

Saudi EFL learners suffer from correct utterances in certain cases in both vowel and consonant sound like $\mathrm{P} / /$ and $\mathrm{B} / /$. Due to such difficulty, students in most cases commit mistakes in writing spelling like 'blease' instead of 'please'.

\section{Linguistic Barriers:}

Students are very weak in vocabulary, grammar issues, such as- syntax, morphology, spelling, sentence structures, and so on. Moreover, Arabic and English having linguistic dissimilarities in many aspects affect Saudi EFL learners negatively though it is common to all EFL context and situation.

\section{Medium of Instruction:}

English being the medium of instruction in tertiary level creates problems for the Prep Year students. To them, it is a sudden change in the system of instruction in the classroom.

\section{Absenteeism and Culture of Excuses:}

JCC experiences its students' high rate of absenteeism in formal classes. Moreover, students enjoy the opportunity of excuses based on some reasons and so, they care a little of attending the classes. It seriously affects students' learning and achievement.

\section{Diploma Certificate \& Stipend Policy:}

Students' demotivation to learning in JCC seems to be the reason behind offering diploma certificate which is not fulfilling the needs of the job market and less demandable. Consequently, after graduation students find difficulty to secure a suitable job. In addition, students from different colleges enjoy financial stipend facility except JCC students. It develops in students a demotivating tendency to studies.

\section{Issues of Viable Suggestion:}

Behind the detours, bumps and barriers to learning, this study analysis found the following viable suggestions: 
I. The most of the participants suggest that using technology in instructional process can be a boosting point in motivating students' zeal for learning. Technology-mediated teachinglearning situation captivates and motivates students' immersion in learning more than teacher-centred pedagogy.

II. It is essential to formulate textual materials assimilating students' background knowledge as well as integrating learners' socio-cultural contents. Additionally, textbook must lay emphasis more on the areas of grammatical, phonological and communicative practical issues.

III. To break the barriers to learning needs to create a congenial and optimal EFL learning environment (e.g., by setting up students' residential hall/ opening up General academic/extra-curricular program).

IV. To change students' attitude, incentive/stipend opportunity can be facilitated based on semester-wise academic result.

V. To boost-up learners' communication skill necessitates activating English Language Club for creating a space and platform for speaking \& listening practice.

Despite numerous debacles and fiascos in teaching and learning EFL in Saudi context or anywhere else, teachers must be skilled at lowering these barriers and sparking students' interest and curiosity by tapping the problems into solutions and by developing a creative, practical and passionate curriculum. So, it is indeed "the best way to fight something is not to oppose it but rather to harness its own energy and convert that energy into learning" (MacLean, 2010).

\section{CONCLUSION}

This paper divulges some significant issues and implications for harnessing the barriers which have impact on students' learning English at JCC of Jazan University. To surpass the barriers affecting students' learning negatively, first, course contents need to reshuffle assimilating issues related to Saudi socio-cultural background. If we want students' ELL to be effective, "the texts should be culturally relevant to the experience of the students" (Bacon \& Finneman, 1990, pp. 459-473). Secondly, university intensive English courses should assimilate learners' intermediate and secondary background knowledge. More clearly speaking, Course syllabus should be redesigned in keeping with the learners' standard and previous learning. Thirdly, JCC English club needs to be activated in order to promote students' speaking and listening skills. Fourthly, technology-mediated teaching-learning method needs to be introduced for captivating and motivating students' immersion in learning. Fifthly, to reduce the rate of absenteeism, JCC administration should be strict and stipend policy can be considered if possible. Additionally, the status of Diploma Certificate needs to consider in viewing the demand of the job market. Finally, the teaching methodology needs to be task-based and full of student-oriented facilitating higher degree of teacher-student interaction and promoting collaborative learning. This is the magic of modern pedagogy. It replaces teacher-dominated lesson practices to learner-centric class activities. It is expected that by adapting the recommendations aforementioned, an effective $21^{\text {st }}$ century technologically driven teaching model classroom can create a new horizon in enhancing learning domain to facilitate students to learn, and to operate knowledge in the light of their needs. In addition, the findings of the present paper will throw useful light on 
the ELT experts, ESL/EFL teachers, JCC administration \& students, curriculum designers and researchers who dream of a successful and an effective learner-centred inclusive teaching/learning platform.

\section{Acknowledgement}

The author of this study expresses his thanks and gratitude to Community College, Jazan University, Jazan, Saudi Arabia for permitting to administer interview survey.

\section{REFERENCES}

Alfallaj, F. (2013, September سبتمبر). The Use of Linguistics in Teaching Pronunciation to Saudi Students. (Journal of Human Sciences) مجلة العلوم الانسانية 14(2), 134-143.

Akasha, O. (2013, October). Exploring the Challenges Facing Arabic-Speaking ESL Students \& Teachers in Middle School. Journal of ELT and Applied Linguistics (JELTAL), 1( 1), 12-31.

Bacon, S., \& Finneman, M. (1990). A study of attitudes, motives, and strategies of university foreign language students and their disposition to authentic oral and written input. The Modern Language Journal, 74(4), 459-473.

Brisk, M. E. (2010). Learning English as a second language. In S. M, \& C. W. L (Eds.), The education of English language learners (pp. 152-173). New York: The Guilford Press.

Creswell, J. W. (2003). Research Design: Qualitative, Quantitative, and Mixed Approaches. Second Revised ed. London: Sage Publications Ltd.

Fadda, H. A. (2012, March). Difficulties in Academic Writing: From the Perspective of King Saud University Postgraduate Students. English Language Teaching, 5(3), 123-130.

Huwari, I. F., \& Khasawneh, F. M. (2013). The Reasons behind the Weaknesses of Writing in English among Pre-year Students' at Taibah University. English for Specific Purposes World, 14(38), 1-9.

Javid, C. Z., \& Umer, M. (2014). Saudi EFL learners' writing problems: a move towards solution. Proceeding of the Global Summit on Education GSE 2014 (pp. 164-180). Kuala Lumpur, Malaysia: WorldConferences.net.

Khan, I. A. (2011). Challenges of Teaching/Learning English and Management. Global Journal Of Human Social Science, 11(8), 68-80.

Khan, I. A. (2011). Learning difficulties in English: Diagnosis and pedagogy in Saudi Arabia. Educational Research, 2(7), 1248-1257.

Khatib, H. (2013, December). Can Universal Linguistic Fundamentals Contribute To The Interpretation Of Efl Learning? European Scientific Journal, 9(35), 28-43.

Knowles, E. (2006). "variety is the spice of life.". Retrieved December 12, 2015, from The Oxford Dictionary of Phrase and Fable: http://www.encyclopedia.com/doc/1O214varietyisthespiceoflife.html

Lee, W. (1995). Authenticity revisited: text authenticity and learner authenticity. ELT Journal, 49(4), 323-328.

MacLean, G. (2010). Three Mobile Phone Applications for EFL Classrooms. In J. Herrington, \& C. Montgomerie (Ed.), Proceedings of EdMedia: World Conference on Educational Media and Technology 2010 (p. 3982). Toronto: Association for the Advancement of Computing in Education (AACE). 
Marshall, C., \& Rossman, G. B. (2006). Designing Qualitative Research. London: Sage Publications Ltd. (Inc 1st pub. 1989).

Rajab, H. (2013). Developing Speaking and Writing Skills of L1 Arabic EFL Learners through Teaching of IPA Phonetic Codes. Theory and Practice in Language Studies, 3(4), 653-659.

Ryhan, E. (2014). The Role and Impact of English as a Language and a Medium of Instruction in Saudi Higher Education Institutions:Students-Instructors Perspective. Study in English Language Teaching, 2(2), 140-148.

Santos, S., \& Suleiman, M. (1993). Teaching English to Arabic-speaking students: cultural and linguistic considerations. Proceedings of the National Annual Association for Bilingual Education Conferences, (pp. 175-180). Washington, DC.

Tsao, C. H. (2011). English for Specific Purposes in the EFL Context: A Survey of Student and Faculty Perceptions. The Asian ESP Journal, 7(2), 126-149.

Zughoul, M. R., \& Taminian, L. (1984). "The linguistic attitude of Arab university students: factorial structure and intervening variables". "The linguistic attitude of Arab university students: factorialThe International Journal of the Sociology of Language, 1984(50), 155-179.

\section{Appendix}

\section{Profile 1}

This study administered a semi-interview with teachers and administrators at JCC in order to find out the ground reality behind students' barriers to learning English language at Jazan University. The interviewees were quite willing to comment and spelt out the issues asked for. Some of them but not all are introduced here in the schedule below:

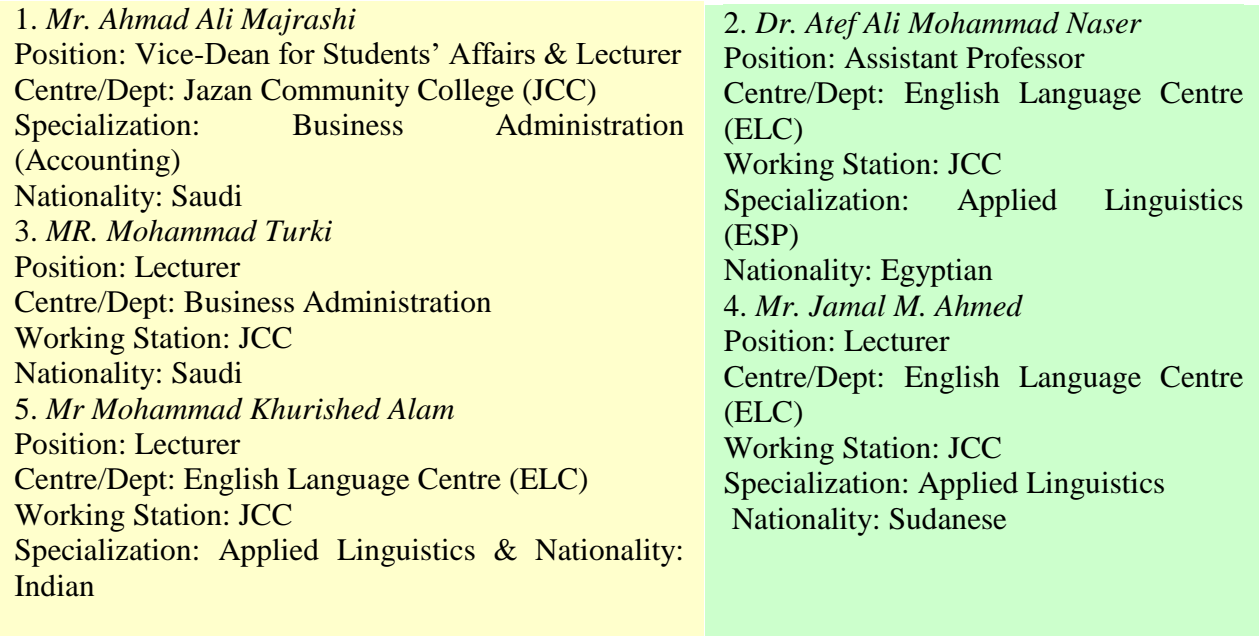

\section{The Interview Questionnaire}

1. What are the obstacles and barriers that you experience affecting students' learning at JCC?

2. What's your suggestion to improve students' learning English? 


\section{Turkish Abstract \\ Öğrencilerin İngilizce Dilini Öğrenmelerindeki Bariyerleri Ortadan Kaldırmak}

Bu çalışma Suudi Arabistan Jazan Üniversitesinde hazırlık düzeyinde öğrencilerin İngilizce'yi ögrenmeleri üzerinde etki sahibi olan akademik, ders müfredat sistemi ve sosyo-kültürel konular açısından engelleri kaldırmayı amaçlamaktadır. Bu çalışma öğretmen ve yöneticilerle olan yarı görüşmelere ve sınıf gözlemlerine dayanarak öğrencilerin öğrenme/öğretme katılımlarına ve gelişmelerine etki eden faktörler üzerinde yoğunlaşmaktadır. Yazar görüşme sürecini bir ankete dayalı olarak yürütmüş ve görüşülenlerin düşünceleri not edilmiştir. Veriler nitel ve nicel olarak analiz edilmiştir. Araştırmanın sonuçları tahmin edildiği gibi şaşırtıcı ve öğretimin etkililiği için tüm paydaşlara düzeltmeler ve eğitimsel geliştirmeler sunmaktadır. Verilerin analizi görüşülenlerin İngilizce öğrenmeye karşı olumsuz tutumlarının kültürel faktörlere, motivasyon eksikliğine ve üniversite öncesinde İngilizce öğretme metod ve müfredatında stratejik eksikliklere dayandığını göstermiştir. Ayrıca, çalışma yapılan araştırma bulgularına dayanarak etkili ve uygulanabilir bazı öneriler de sunmuştur.

Anahtar Kelimeler: iletişimsel yeterlik, linguistik engeller, sosyo-kültürel farkındalık, öğrenme amaçlı İngilizce, İngilizce öğrenenler

\section{French Abstract}

L'exploitation des Barrières qui Ont un impact sur la langue anglaise des Étudiants Apprenant (ELL)

Cette étude s'efforce de choisir les barrières et les obstacles en termes d'universitaire, le système de programme d'études de cours et des questions socioculturelles, cet impact sur la langue anglaise d'apprentissage des étudiants défavorablement dans le niveau d'année préparatoire à l'Université Jazan, l'Arabie Saoudite. Ce papier se concentre particulièrement sur les facteurs affectant EFL (l'anglais langue étrangère) les étudiants enseignent/apprennent l'engagement et la progression au Collège universitaire Jazan (JCC) basé sur semi l'entretien(interview) de professeurs, des administrateurs et des observations de salle de classe. L'auteur a administré le processus d'entretien(interview) basé sur un questionnaire et en même temps, les réflexions(reflets) des interviewés(candidats) ont été notées en bas. Les données enregistrées ont été analysées qualitativement et quantitativement. Les résultats de la recherche sont des améliorations éducatives EFL comme on pouvait s'y attendre surprenantes et contribuantes et des rajustements pour toutes les parties prenantes en termes d'efficacité d'instruction. L'analyse de données a en particulier montré que la plupart des voix d'interview reflètent la position négative des étudiants vers l'apprentissage de l'anglais en raison des facteurs multiculturels, le manque de motivation et EFL la méthode enseignante et le programme d'études des défauts stratégiques dans l'étape pré universitaire. De plus, ce papier formule une hypothèse quelques suggestions effectives et viables basées sur l'enquête de recherche.

Mots Clés: la compétence communicative, des barrières linguistiques, la conscience socioculturelle, l'anglais pour apprendre des buts, des apprenants anglais ( ELS)

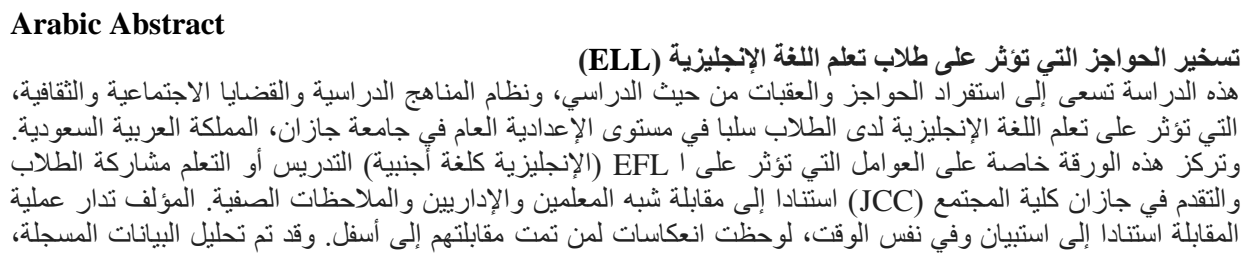

International Journal of Instruction, July $2016 \bullet$ Vol.9, No.2 


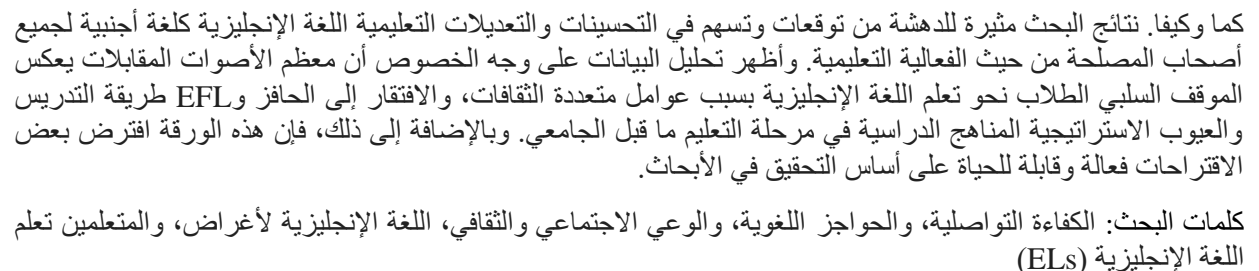

\section{German Abstract}

Die Barrieren Nutzbar Zu Machen, Die Auswirkungen Auf Erlernen Der Englischen Sprache Von Studenten

Diese Studie ist bestrebt, die Barrieren und Hindernisse in Bezug auf die akademischen, Lehrplan System und sozio-kulturelle Fragen, die Auswirkungen auf das Lernen der Studierenden in englischer Sprache negativ im Vorbereitungsjahr Ebene an Jazan Universität, Saudi-Arabien, einzelne aus. Dieser Beitrag konzentriert sich vor allem auf die Faktoren, die EAF (Englisch als Fremdsprache) Schülers Lehr-/Lern Engagement und Progression bei Jazan Community College (JCC), basierend auf dem Halb Interview von Lehrern, Administratoren und Unterrichtsbeobachtungen. Der Autor der Interview-Prozess auf einem Fragebogen basiert verwaltet und zugleich, die Befragten Reflexe wurden notiert. Die aufgezeichneten Daten wurden qualitativ und quantitativ analysiert. Die Ergebnisse der Forschung sind erwartungsgemäß überraschend und in Bezug auf die Lehr-Effizienz für alle Beteiligten zu EAF Bildungs Verbesserungen und Anpassungen beitragen. Die Datenanalyse zeigte insbesondere, dass die meisten der Befragung Stimmen ablehnende Haltung der Schüler zum Lernen Englisch aufgrund interkulturelle Faktoren widerspiegelt, fehlende Motivation und EAF Lehrmethode und Lehrplan strategische Mängel in voruniversitären Bühne. Darüber hinaus stellt die Hypothese auf dieses Papier einige wirksame und praktikable Vorschläge stützen sich auf Forschungs Untersuchung.

Schlüsselwörter: kommunikative kompetenz, sprachbarrieren, soziokulturelle bewusstsein, englisch für zwecke, Englisch lerner (ELs)

\section{Malaysian Abstract \\ Memanfaatkan Halangan Kesan ke atas Pembelajaran Bahasa Inggeris Pelajar (ELL)}

Kajian ini berusaha untuk satu daripada halangan dan halangan dari segi akademik, sistem kurikulum kursus dan isu-isu sosio-budaya, yang memberi kesan kepada pembelajaran bahasa Inggeris pelajar buruk di peringkat tahun prep di Jazan University, Arab Saudi. Kertas kerja ini terutamanya memberi tumpuan kepada faktor-faktor yang mempengaruhi EFL (Bahasa Inggeris sebagai Bahasa Asing) pengajaran pembelajaran penglibatan pelajar / dan perkembangan di Kolej Komuniti Jazan (JCC) berdasarkan temu bual separa struktur oleh guru, pentadbir dan pemerhatian bilik darjah. Pengkaji mentadbir proses temu bual berdasarkan soal selidik dan pada masa yang sama, maklum balas daripada ditemu bual dicatatkan. Data yang direkodkan dianalisis secara kualitatif dan kuantitatif. Keputusan kajian ini ialah menyumbang penambahbaikan EFL pendidikan dan pelarasan bagi semua pihak yang berkepentingan dari segi keberkesanan pengajaran. Analisis data khususnya menunjukkan kebanyakan maklum balas temu bual mencerminkan sikap negatif pelajar terhadap pembelajaran Bahasa Inggeris kerana faktor silang budaya, kekurangan motivasi dan kaedah pengajaran EFL dan kecacatan strategik kurikulum di peringkat pra-universiti. Di samping itu, kertas kerja ini membuat hipotesis berdasarkan analogi beberapa cadangan yang berkesan dan berdaya maju berdasarkan siasatan penyelidikan.

Kata Kunci: kompetensi komunikasi, halangan bahasa, kesedaran sosial budaya, tujuan pembelajaran English, English learners (ELs) 